\title{
Pseudoporphyria secondary to renal failure
}

\section{Pseudoporfiria w przebiegu niewydolności nerek}

\author{
Lilianna Kulczycka-Siennicka', Anna Woźniacka', Remigiusz Szumiński², Agnieszka Żebrowska'
}

'Department of Dermatology and Venereology, Medical University of Lodz, Poland

${ }^{2} \mathrm{NZOZ}$ B. Braun Avitum Poland Sp. z O.O., Dialysis Station, Zgierz, Poland

IKlinika Dermatologii i Wenerologii Uniwersytetu Medycznego w Łodzi, Polska

${ }^{2}$ NZOZ B. Braun Avitum Poland Sp. z o.o., Stacja Dializ w Zgierzu, Polska

Dermatol Rev/Przegl Dermatol 2017, 104, 122-127 DOI: https://doi.org//0.5।|4/dr.2017.67386

\author{
CORRESPONDING AUTHOR/ \\ ADRES DO KORESPONDENCJI: \\ dr n. med. Lilianna Kulczycka- \\ -Siennicka \\ Klinika Dermatologii \\ i Wenerologii \\ Uniwersytet Medyczny w Łodzi \\ pl. Hallera 1, budynek 6 \\ 90-647 Łódź, Polska \\ e-mail: lilakulczycka@wp.pl
}

\begin{abstract}
Introduction. Pseudoporphyria is a rare disease associated with chronic renal failure. Symptoms of pseudoporphyria may develop in response to UV exposure and medications. The literature reports cases of pseudoporphyria in patients infected with hepatis $\mathrm{C}$ virus, HIV and undergoing dialysis therapy.

Objective. Presentation of the case of a patient with pseudoporphyria and uraemic pruritus, and overview of therapeutic management.

Case report. A 64-year-old male patient, who had been on dialysis for chronic renal failure secondary to type 2 diabetes for the past 11 years, presented with tense bullae located on sun-exposed skin which had persisted for the previous 5 months. The patient was diagnosed with pseudoporphyria, and treatment was prescribed including N-acetylcysteine, chloroquine, paroxetine and mianserin. An improvement in the patient's clinical condition and a regression of pruritus were achieved.

Conclusions. Patients with renal failure may develop symptoms of pseudoporphyria requiring differentiation from porphyria cutanea tarda.
\end{abstract}

\section{STRESZCZENIE}

Wprowadzenie. Pseudoporfiria jest rzadką jednostką chorobową związaną z przewlekłą niewydolnością nerek. Wystąpienie objawów pseudoporfirii może być wywołane ekspozycją na promieniowanie ultrafioletowe oraz leki. W piśmiennictwie istnieją opisy występowania pseudoporfirii u pacjentów zakażonych wirusem zapalenia wątroby typu C i HIV oraz u pacjentów dializowanych.

Cel pracy. Przedstawienie przypadku pacjenta z pseudoporfirią i świądem mocznicowym oraz omówienie postępowania leczniczego.

Opis przypadku. Mężczyzna 64-letni, od 11 lat dializowany z powodu przewlekłej niewydolności nerek w przebiegu cukrzycy typu 2, zgłosił się z powodu występujących od 5 miesięcy pęcherzy o dobrze napiętej pokrywie zlokalizowanych w obrębie skóry eksponowanej na promieniowanie słoneczne. U pacjenta rozpoznano pseudoporfirię, a w leczeniu zastosowano: $\mathrm{N}$-acetylocysteinę, chlorochinę, paroksetynę oraz mianserynę. Uzyskano poprawę kliniczną i ustąpienie świądu skóry. 
Wnioski. U pacjentów z niewydolnością nerek mogą wystąpić objawy psedoporfirii wymagającej różnicowania z porfirią skórną późną.

Key words: dialysis therapy, pseudoporphyria, chloroquine, renal failure, porphyria cutanea tarda.

Słowa kluczowe: dializoterapia, pseudoporfiria, chlorochina, niewydolność nerek, porfiria skórna późna.

\section{INTRODUCTION}

Pseudoporphyria (PP) is a relatively rare disease which shows both clinical and histopathological resemblance to porphyria cutanea tarda (PCT). The difference between the two conditions is that PP does not present as elevated porphyrin levels in blood serum, urine and faeces. These abnormalities, however, are very characteristic of PCT. Pseudoporphyria symptoms can be induced by a number of factors such as exposure to UV radiation including artificial UVA and UVB sources, and medications including nonsteroidal anti-inflammatory drugs, retinoids, antibiotics, diuretics, antifungal medicines and oral contraceptives [1]. Furthermore, there are literature reports of $\mathrm{PP}$ occurring in patients infected with hepatis $\mathrm{C}$ virus (HCV), HIV and undergoing dialysis therapy $[1,2]$.

Porphyria cutanea tarda is the most common type of porphyria, and can be categorized as acquired (markedly more common) and familial (inherited). The underlying cause of the disease is a defect in uroporphyrinogen III decarboxylase (UROD) - an enzyme responsible for the conversion of uroporphyrinogen III to coproporphyrinogen III. The activity of the enzyme in the liver is inhibited by external factors including medications, alcohol and also infections (mainly HCV). In effect, the levels of all porphyrins, particularly uroporphyrins and highly carboxylated porphyrins, become elevated. The clinical picture is characterized primarily by typical skin changes in the form of tense bullae located in sun-exposed areas, erosions, scarring and milia, increased skin fragility, hypertrichosis in the temporal facial areas, scleroderma-like lesions on the face and trunk, hyperpigmentation and skin photosensitivity [3].

\section{OBJECTIVE}

Presentation of the case of a 64-year-old male patient with PP, and overview of modalities available for the treatment of the disease.

\section{WPROWADZENIE}

Pseudoporfiria (PP) to dość rzadka choroba, której obrazy - zarówno kliniczny, jak i histopatologiczny - przypominają obraz porfirii skórnej późnej (PCT). Różnica polega na tym, że w przebiegu PP nie występują podwyższone stężenia porfiryn w surowicy, moczu i kale. Te nieprawidłowości są bardzo charakterystyczne dla PCT. Wystąpienie objawów PP może być indukowane przez liczne czynniki, takie jak ekspozycja na promieniowanie ultrafioletowe (UV), w tym sztuczne źródła UVA i UVB, leki: niesteroidowe leki przeciwzapalne, retinoidy, antybiotyki, diuretyki, leki przeciwgrzybicze, jak również doustne leki antykoncepcyjne [1]. W piśmiennictwie dostępne są ponadto dane opisujące występowanie PP u pacjentów zakażonych wirusem zapalenia wątroby typu C (HCV), HIV oraz pacjentów dializowanych [1, 2].

Porfiria skórna późna jest najczęściej spotykaną postacią porfirii, występującą w odmianach: nabytej (zdecydowanie częstszej) i wrodzonej. U podstawy rozwoju choroby leży defekt dekarboksylazy uroporfirynogenu III (UROD) - enzymu odpowiadającego za przekształcanie uroporfirynogenu III w koproporfirynogen III. Wpływ czynników zewnętrznych, takich jak leki i alkohol, jak również zakażeń (głównie HCV), blokuje działanie enzymu w wątrobie. W konsekwencji dochodzi do podwyższenia poziomu wszystkich porfiryn, zwłaszcza uroporfiryn oraz porfiryn wysoce karboksylowanych. W obrazie klinicznym przeważają charakterystyczne zmiany skórne: pęcherze o dobrze napiętych pokrywach zlokalizowane $\mathrm{w}$ miejscach eksponowanych na promieniowanie słoneczne, nadżerki, blizny i prosaki, wzmożona urażalność skóry, hipertrichoza w obrębie skroni, zmiany twardzinopodobne na twarzy i tułowiu, przebarwienia oraz nadwrażliwość skóry na promieniowanie słoneczne [3].

\section{CEL PRACY}

Przedstawienie przypadku 64-letniego pacjenta z PP oraz możliwości terapeutycznych w tej jednostce chorobowej. 


\section{CASE REPORT}

A 64-year-old man, who had been on dialysis for chronic renal failure secondary to type 2 diabetes for the past 11 years, presented to a dermatology outpatient clinic with cutaneous lesions present over the preceding 5 months and including tense bullae located on the scalp, auricles and dorsal hand surfaces (Figs. 1, 2). The symptoms enumerated above were accompanied by very severe generalized pruritus leading to sleep disturbances. The severity of itch was rated by the patient at over 10 in the Numeric Rating Scale (NRS). Porphyria cutanea tarda or pemphigoid was suspected. The results of laboratory tests conducted at the Dialysis Station (CBC; AST and ALT; iron, ferritin, urea and creatinine levels) showed no abnormalities. During that time the patient already received regular dialysis treatment. $\mathrm{HCV}, \mathrm{HBV}$ and HIV infections were excluded. Also, the level of porphyrins determined in a 24-hour urine sample was within the normal range. The histopathological results suggested the diagnosis of a blistering skin disease. However, immunofluorescence tests (DIF and IIF) failed to confirm the diagnosis of any of the autoimmune blistering diseases. A repeated histopathological examination gave a result that was consistent with the diagnosis of porphyria, excluding pemphigoid.

Based on the clinical picture combined with laboratory test results, the diagnosis of dialysis-induced PP was made. Initially, it was decided to start treatment with $\mathrm{N}$-acetylcysteine at $800 \mathrm{mg} /$ day. To reduce pruritus, a variety of topical agents were applied including 10\% urea, menthol, polidocanol and 0.025\% capsaicin. A strict photoprotection regimen was ad-

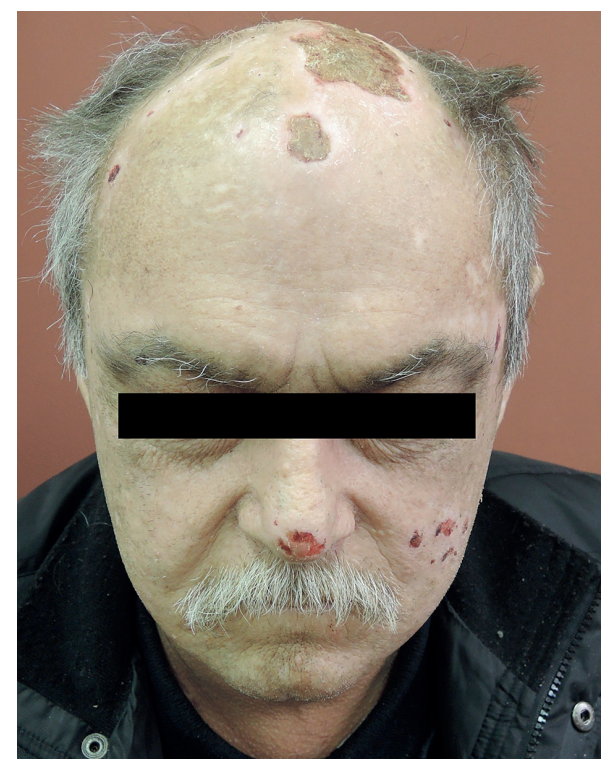

Figure I. Pseudoporphyria - erosions on the scalp and face Rycina I. Pseudoporfiria - nadżerki w obrębie skóry owłosionej głowy i twarzy

\section{OPIS PRZYPADKU}

Mężczyzna, lat 64, dializowany od 11 lat ze względu na niewydolność nerek w przebiegu cukrzycy typu 2, zgłosił się do poradni dermatologicznej z powodu obecnych od 5 miesięcy zmian skórnych w postaci pęcherzy o dobrze napiętych pokrywach zlokalizowanych w obrębie skóry owłosionej głowy, małżowin usznych oraz grzbietów rąk (ryc. 1, 2). Towarzyszył im bardzo intensywny, uogólniony świąd prowadzący do zaburzeń snu. Intensywność świądu została oceniona przez pacjenta na więcej niż 10 wg Numeric Rating Scale (NRS). Wysunięto podejrzenie porfirii skórnej późnej lub pemfigoidu. Wyniki badań laboratoryjnych wykonanych w stacji dializ (morfologia, AspAT, AlAT, stężenie żelaza, ferrytyny, mocznika, kreatyniny) były prawidłowe. W tym czasie pacjent był już regularnie dializowany. Wykluczono zakażenie HCV, HBV i HIV. Poza tym wykazano prawidłowe stężenie porfiryn w dobowej zbiórce moczu. Wynik badania histopatologicznego sugerował rozpoznanie choroby peccherzowej. Wyniki badań immunologicznych (DIF i IIF) nie potwierdziły jednak rozpoznania żadnej z autoimmunologicznych chorób pęcherzowych. Ponownie wykonano badanie histopatologiczne, a uzyskany wynik wskazywał na rozpoznanie porfirii, wykluczając pemfigoid.

Na podstawie obrazu klinicznego oraz wyników badań laboratoryjnych ustalono rozpoznanie PP indukowanej dializami. Początkowo zdecydowano o włączeniu N-acetylocysteiny w dawce $800 \mathrm{mg} /$ dobę. W celu redukcji świądu stosowano różne preparaty miejscowe zawierające kolejno: 10\% mocznik,

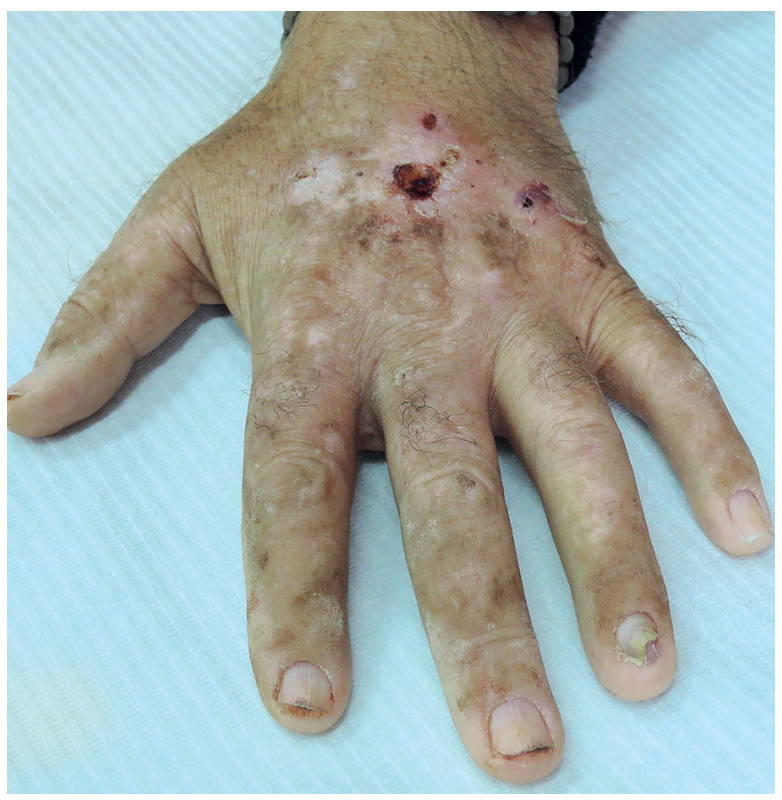

Figure 2. Involvement of dorsal hand surfaces

Rycina 2. Zajęcie grzbietów rąk 
vised. As the patient's tolerance of systemic therapy was poor and no improvement was noted, the therapy was discontinued a month after initiation and substituted for chloroquine at $125 \mathrm{mg}$ twice a week, with a good tolerance. The severity of cutaneous lesions decreased over the following 2 weeks. As there was no relief in pruritus, and the patient reported depressive symptoms and progressive sleep disturbances, paroxetine was started at $20 \mathrm{mg} /$ day. The drug was used for 4 weeks, however no improvement was observed, so paroxetine was substituted for mianserin at a starting dose of $10 \mathrm{mg} /$ day with the possibility to increase the dose to a maximum of $30 \mathrm{mg} /$ day. After 3 months of treatment, the skin lesions subsided and the severity of pruritus was considerably reduced, with the patient rating it at 2 on the NRS scale.

A month after achieving a noticeable improvement, however, the severity of skin lesions and pruritus increased again. There were no modifications in the treatment regimen during that period. The only change was the use of a different dialysis machine. The return to the previous dialysis filter halted the progress of the disease. The bullae subsided, and no new eruptions were noted. The majority of erosions were healed. The skin on the face, head and auricles acquired a slightly waxy appearance accompanied by an increased fragility. In addition, pruritus was successfully relieved following a temporary increase in the dose of mianserin to $30 \mathrm{mg} /$ day. Currently, it only occurs sporadically, and the patient takes mianserin at $10 \mathrm{mg} /$ day, periodically using the drug every other day. Also, the patient reports no sleep disturbances or low moods.

\section{DISCUSSION}

The clinical features of PP and PCT are similar. However, unlike PCT, PP is not associated with hypertrichosis and sclerodermoid lesions [1]. Moreover, the majority of patients with PP show no elevation in porphyrin levels in blood serum, urine and faeces, which are typical of PCT. Nonetheless, patients with end-stage renal disease (ESRD) may have a slightly elevated serum porphyrin level [4].

The data found in the literature indicate that the incidence of PP in the group of patients receiving haemodialysis treatment ranges from 1.2 to $18 \%$, and it is lower in patients treated by peritoneal dialysis [1-3]. A similar incidence rate is noted for PCT (3).

The underlying causes of PP have not been sufficiently elucidated. The disease seems to be associated with insufficient elimination of porphyrins due to renal failure rather than deficient enzymatic activity. However, the accumulation of porphyrins in the skin and blood serum, in conjunction with exposure to UV radiation, leads to the formation of free radicals and mentol, polidokanol i 0,025\% kapsaicynę. Zalecono bezwzględną fotoprotekcję. Chory źle tolerował leczenie ogólne. W wyniku zastosowanej terapii nie uzyskano poprawy i z tego powodu po miesiącu zakończono dotychczasowe leczenie oraz włączono $125 \mathrm{mg}$ chlorochiny 2 razy w tygodniu, z dobrą tolerancją. W ciągu 2 tygodni zmniejszyło się nasilenie zmian skórnych. Ze względu na brak poprawy w zakresie intensywności świądu, zgłaszane objawy depresyjne i narastające problemy ze snem podjęto próbę włączenia paroksetyny w dawce $20 \mathrm{mg}$ / dobę. Lek stosowano przez 4 tygodnie, bez efektu, a następnie mianserynę w wyjściowej dawce 10 mg/dobę, z możliwością podwyższenia do maksymalnie $30 \mathrm{mg} /$ dobę. Po 3 miesiącach leczenia uzyskano ustąpienie zmian skórnych oraz znaczną poprawę w zakresie nasilenia świądu. W tym czasie pacjent oceniał jego intensywność na 2 wg NRS.

Po upływie około miesiąca od uzyskania zauważalnej poprawy doszło jednak do ponownego nasilenia zarówno zmian skórnych, jak i świądu. W tym czasie nie modyfikowano leczenia. Jedyną zmianą było wprowadzenie innego dializatora. Powrót do poprzedniego rodzaju filtra zahamował postęp choroby. Pęcherze ustąpiły, nie pojawiały się nowe. Większość nadżerek się zagoiła. Skóra twarzy, głowy oraz małżowin usznych przybrała nieco woskowe zabarwienie, z towarzyszącą wzmożoną urażalnością. Ponadto uzyskano ustąpienie świądu (konieczne było przejściowe zwiększenie dawki mianseryny do $30 \mathrm{mg}$ / dobę). Obecnie pojawia się sporadycznie, a pacjent przyjmuje mianserynę w dawce $10 \mathrm{mg} /$ dobę, okresowo stosując lek co 2. dzień. Mężczyzna nie zgłasza również zaburzeń snu oraz spadków nastroju.

\section{OMÓWIENIE}

Obraz kliniczny PP jest zbliżony do PCT. W przebiegu PP nie występują jednak hipertrichoza oraz zmiany stwardnieniowe [1]. Poza tym u większości pacjentów nie stwierdza się podwyższonych stężeń porfiryn w surowicy, moczu i kale, jak w przypadku PCT. Niemniej pacjenci ze schyłkową niewydolnością nerek (ESRD) mogą mieć nieznacznie podwyższone stężenie porfiryn w surowicy [4].

Dane z piśmiennictwa wskazują, że częstość występowania PP u pacjentów hemodializowanych wynosi 1,2-18\%, a u pacjentów, u których przeprowadza się dializy otrzewnowe, jest mniejsza [1-3]. Podobna jest częstość występowania PCT [3].

Przyczyny rozwoju PP nie są do końca wyjaśnione. Wydaje się, że znaczenie ma niedostateczne usuwanie porfiryn wynikające z niewydolności nerek, a nie brak pełnej aktywności enzymu. Niemniej ich gromadzenie się w skórze i surowicy w połącze- 
ultimately contributes to tissue damage and the development of bullae. It is important to note, though, that not every patient on dialysis experiences such symptoms. Furthermore, patients with ESRD have characteristically reduced glutathione levels in the plasma and erythrocytes, which contributes to the development of UV radiation hypersensitivity even at normal porphyrin levels [5]. Some of the literature data also indicate a link to azotaemia, which has an effect on reducing the activity of uroporphyrinogen decarboxylase [2].

The recommended therapeutic regimen comprises photoprotection, and treatment with $\mathrm{N}$-acetylcysteine or chloroquine $[1,4,6]$. The theoretical efficacy of $\mathrm{N}$-acetylcysteine is due to its role as a precursor of glutathione which displays antioxidant properties and, at the same time, reduces the level of creatinine [7]. However, the literature reports show that this therapeutic regimen is not always effective [5], which is also evident in the case reported here. Antimalarial medicines may be effective but only in patients with normal micturition. In patients with anuria, however, this treatment modality is unsuccessful [1]. The firstline drug is chloroquine. There is a literature report on the inefficacy of hydroxychloroquine in the therapy of PP which is most likely attributable to differences in size between chloroquine and hydroxychloroquine molecules [2].

The severity of pruritus in our patient was assessed using an 11-point NRS scale which represents a variant of the Visual Analogue Scale (VAS). Based on the available literature, both scales can be recognized as appropriate for the assessment of the severity of pruritus in clinical trials, and they produce similar results [8]. It is therefore warranted to treat both scales as equivalent in the assessment of pain severity, which can also be extrapolated to the assessment of pruritus severity. The patient specifies a number which corresponds to the perceived severity of pruritus associated with the disease, where 0 is defined as no itch and 10 is the worst itch imaginable $[9,10]$. The assessment of pruritus severity applied to the previous 3 days.

The persistent generalized pruritus reported by the patient was related to renal failure rather than PP, as in the latter case the symptom is localized. Since topical treatment failed to produce an improvement, and phototherapy was contraindicated, it was decided to initiate antidepressant therapy. Consequently, in addition to stabilizing the patient's mood, the treatment contributed to relieving pruritus.

In addition to meticulous nephrological care patients with renal failure also need special dermatological attention. In many cases, the coexistence of multiple skin problems with renal failure represents a major therapeutic challenge. niu z ekspozycją na promieniowanie ultrafioletowe (UV) powoduje powstawanie wolnych rodników, a to $\mathrm{w}$ konsekwencji przyczynia się uszkodzenia tkanek i powstawania pęcherzy. Należy zaznaczyć, że nie u każdego dializowanego pacjenta dochodzi do rozwoju tego rodzaju objawów. Ponadto chorych z ESRD charakteryzuje zmniejszone stężenie glutationu w osoczu i erytrocytach, co przyczynia się do rozwoju nadwrażliwości na UV nawet przy prawidłowym poziomie porfiryn [5]. W piśmiennictwie dostępne są również dane wskazujące na związek z azotemią, która wpływa na obniżenie aktywności dekarboksylazy uroporfirynogenu [2].

$\mathrm{W}$ terapii zaleca się fotoprotekcję oraz $\mathrm{N}$-acetylocysteinę lub chlorochinę $[1,4,6]$. Teoretyczna skuteczność N-acetylocysteiny wynika z faktu, że jest ona prekursorem glutationu, który ma zdolności antyoksydacyjne, a jednocześnie obniża stężenie kreatyniny [7]. Dane z piśmiennictwa wskazują jednak, że nie zawsze ten sposób leczenia jest skuteczny [5], co potwierdza również opisany przez nas przypadek. Leki przeciwmalaryczne mogą być skuteczne, ale tylko u chorych oddających mocz. W przypadku anurii takie postępowanie nie przynosi efektu [1]. Za lek pierwszego rzutu uważa się chlorochinę. W piśmiennictwie dostępny jest opis dotyczący nieskuteczności hydroksychlorochiny w terapii PP, która wynika najprawdopodobniej z różnic w wielkości cząsteczek chlorochiny i hydroksychlorochiny [2].

U naszego pacjenta do oceny stopnia nasilenia świądu uży to 11-stopniowej skali NRS, stanowiącej odmianę VAS. Dane z piśmiennictwa wskazują, że obie skale mogą być stosowane do oceny nasilenia świądu w badaniach klinicznych, a uzyskiwane wyniki są porównywalne [8]. Daje to podstawy do uznania równoważności tych skal w ocenie natężenia bólu, co można również odnieść do oceny natężenia świądu. Pacjent podaje cyfrę odpowiadającą intensywności świądu, jaki odczuwa w przebiegu choroby, przy czym 0 oznacza brak świądu, a 10 najbardziej intensywny świąd, jaki badany może sobie wyobrazić $[9,10]$. Ocena intensywności świądu dotyczyła 3 ostatnich dni.

Uporczywy, uogólniony świąd zgłaszany przez pacjenta wiązał się z niewydolnością nerek, a nie PP, w przebiegu której objaw ten ma charakter zlokalizowany. Ze względu na brak poprawy po leczeniu miejscowym oraz przeciwwskazania do fototerapii zdecydowano o podjęciu próby włączenia leczenia przeciwdepresyjnego. Przyczyniło się ono do stabilizacji nastroju pacjenta i ustąpienia świądu.

Pacjenci z niewydolnością nerek wymagają troskliwej opieki nie tylko nefrologicznej, lecz także dermatologicznej. Niejednokrotnie współistnienie kilku problemów skórnych z niewydolnością nerek stanowi wyzwanie terapeutyczne. 
The authors declare no conflict of interest.

\section{KONFLIKT INTERESÓW}

Autorzy deklarują brak konfliktu interesów.

\section{References}

\section{Piśmiennictwo}

1. Markova A., Lester J., Wang J., Robinson-Bostom L.: Diagnosis of common dermatopathies in dialysis patients: a review and update. Semin Dial 2012, 25, 408-418.

2. Fevang S.A., Kroon S., Skadberg Ø.: Pseudoporphyria or porphyria cutanea tarda? Diagnostic and treatment difficulties. Acta Derm Venereol 2008, 88, 426-427.

3. Robinson-Bostom L., Di Giovanna J.J.: Cutaneous manifestations of end-stage renal disease. J Am Acad Dermatol 2000, 43, 975-986.

4. Katoulis A.C., Ferra D., Toumbis E., Papadavid E., Kanelleas A., Panayiotides I., et al.: Pseudoporphyria associated with nonhemodialyzed renal insufficiency, successfully treated with oral N-acetylcysteine. Case Rep Dermatol Med 2013, doi: $10.1155 / 2013 / 271873$.

5. El Kabbaj D., Laalou A., Alouane Z., Bahadi A., Oualim Z.: Hemodialysis-associated pseudoporphyria resistant to N-acetylcysteine. Saudi J Kidney Dis Transpl 2011, 22, 311-314

6. Bergler-Czop B., Brzezińska-Wcisło L.: Pseudoporphyria induced by hemodialysis. Postep Dermatol Alergol 2014, 31, 53-55.

7. Guiotoku M.M., Pereira F. de P., Miot H.A., Marques M.E.: Pseudoporphyria induced by dialysis treated with oral N-acetylcysteine. An Bras Dermatol 2011, 86, 383-385.

8. Phan N.Q., Blome C., Fritz F., Gerss J., Reich A., Ebata T., et al.: Assessment of pruritus intensity: prospective study on validity and reliability of the visual analogue scale, numerical rating scale and verbal rating scale in 471 patients with chronic pruritus. Acta Derm Venerol 2012, 92, 502-507.

9. Reich A., Heising M., Szepietowski J.C.: Visual analogue scale as a validated assessment of pruritus intensity. Acta Derm Venereol 2009, 89, 688

10. Ständer S., Augustin M., Reich A., Blome C., Ebata T., Phan N.Q., et al.: International Forum for the Study of Itch Special Interest Group Scoring Itch in Clinical Trials. Pruritus assessment in clinical trials: consensus recommendations from the International Forum for the Study of Itch (IFSI) Special Interest Group Scoring Itch in Clinical Trials. Acta Derm Venereol 2013, 93, 509-514.

Received: 17.01 .2017

Accepted: 19.03.2017

Otrzymano: 17.01.2017 r

Zaakceptowano: $19.03 .2017 \mathrm{r}$ 